\title{
KARAITE HEBREW POETRY AND POETICS IN EARLY MODERN EUROPE*
}

\author{
RIIKKA TUORI \\ University Lecturer of Middle Eastern Studies \\ P.O.B. 59, 00014 University of Helsinki, Finland \\ e-mail: riikka.tuori@helsinki.fi
}

\begin{abstract}
Hebrew was the main language of the early modern Karaim culture. Nearly all Polish-Lithuanian Karaim scholars wrote poetry in Hebrew for various occasions celebrating the Karaim cycle of life: for Sabbaths and festivals, for weddings and circumcisions, or as eulogies for a fellow scholar. Their poems cover exegetical, philosophical, and mystical topics from a Karaim point of view and contain historical details about Karaim life in Eastern Europe. Karaim Hebrew poets followed the footsteps of earlier Karaite generations: Byzantine Karaite poetry, emulating the Andalusian standards of poetics and familiarised through shared literary sources, served as their main literary model.
\end{abstract}

Key words: Karaims, Karaites, Hebrew poetry, Karaite Hebrew poetry, Andalusian Hebrew prosody, Poland-Lithuania.

\section{Introduction}

Poetry and poetics played a major role in early modern Karaim culture. ${ }^{1}$ In a recent study, I identified more than two hundred Hebrew poems by Polish-Lithuanian Karaim authors (Tuori 2013, pp. 417-427). An unknown number of poems have

* This article is based on a paper delivered at the Szeged Workshop for Karaim Studies in Szeged, Hungary, June 2014.

${ }^{1}$ I shall use the term 'Karaim' referring to Eastern European Karaims who adhere to Karaite faith. The term 'Karaite' will refer to the adherents of Karaite Jewish faith in general. When referring to the adherents of rabbinic Judaism, I shall use the terms 'Rabbanite' and 'rabbinic'. On transliteration: for Karaim names, the standard Hebrew versions will be used. 
remained scattered in various archives around the world. ${ }^{2}$ The Karaim affection for Hebrew poetry is palpable in the impressive variety of poetic genres they mastered, including scores of liturgical genres, selihot (penitential poems), qinot (lamentations), zemirot (hymns), 'aqedot (poems discussing the binding of Isaac, based on Genesis 22), and baqqashot (petitionary poems), to name a few. ${ }^{3}$ Karaims wrote Hebrew poems to celebrate weddings and religious holidays, or to mourn the death of a relative or a friend. As an exclusive pastime of the male members of the community, ${ }^{4}$ poetry was an instrument for expressing devout feelings, offering didactic guidance, and discussing intricate theological and philosophical topics.

In this article, I offer a concise introduction to one vibrant stratum of Karaim literary culture: the use, form, and function of Hebrew poetry in the Polish-Lithuanian Commonwealth (1569-1795). ${ }^{5}$ Because I shall draw from the results of my dissertation (Tuori 2013), the discussion will be limited to non-liturgical genres, namely, poems written for paraliturgical ${ }^{6}$ events (e.g., Sabbaths, weddings, and circumcisions).

Hebrew poems written by early modern Karaims are extant in manuscripts copied between the 16th and early 20th centuries, as well as in prayer books and other collections of devout literature printed in Eastern Europe. For my dissertation (Tuori 2013), I perused seventeen manuscripts, stored in seven archives in four countries. ${ }^{7}$ The printed Karaite prayer books - for example, the one published in Vilna in 18901892 (Siddur ha-tefillot ke-minhaq haq-qara'im) - contain dozens of original Karaim poems in Hebrew. ${ }^{8}$ Ever since the Byzantine Karaite Aharon ben Yosef (d. 1240)

${ }^{2}$ For an up-to-date collection of research, publications, and archives on Karaites and Karaite Judaism, including a section on Karaism in Eastern Europe, see Walfish and Kizilov (2011).

${ }^{3}$ For various poetic genres in mediaeval Hebrew poetry, see, e.g., Weinberger (1998) and Fleischer (1975). For a concise history of Karaite Hebrew poetry, see Weinberger (1998, pp. 408431). On unfavourable comments by modern scholars on the aesthetic value of Karaite Hebrew poetry, see Tuori (2011).

${ }^{4}$ Hebrew was not part of women's curriculum; on Hebrew learning of boys in Lithuanian Karaite communities, see Kowalski (1929, pp. xiii-xiv).

${ }^{5}$ On the history of the Karaims in early modern Europe, see Mann (1931), Akhiezer and Shapira (2001), Harviainen (2003), and Kizilov (2009). For the history of the Polish-Lithuanian Commonwealth, see, e.g., Gierowski (1996); for the history of Ashkenazi Jews in Poland-Lithuania, see, e.g., Rosman (1990) and Hundert (2004). The article omits the Hebrew poetry written by Crimean Karaims - a topic well worth a comprehensive study in future.

${ }^{6}$ Paraliturgical poems are recited parallel with the public service in the synagogue, for instance, before the beginning of the liturgy, or at homes during ceremonial gatherings and meals (Kollender 2003, p. 476). The division between liturgical (sacred) and non-liturgical (secular) genres in Hebrew poetry is a mediaeval one; see more in Fleischer (1975, pp. 7-8).

${ }^{7}$ Israel (Yad Ben Zvi Institute, Schocken Library, and National Jewish Library in Jerusalem), Russia (Institute of Oriental Studies of the Russian Academy and National Library of Russia in St. Petersburg), Lithuania (Simon Firkovičius karaimiškų rankraščiu kolekcija, Lithuanian Academy of Sciences, Vilnius), and France (Bibliothèque Nationale, Paris).

${ }^{8}$ The Vilna Siddur was edited by Felix (Pinahas) ben Aharon Malecki (1854-1928), the leader of the Lithuanian Karaim community. Malecki added previously unpublished Polish-Lithuanian Karaim poems from local manuscripts while preparing the volume for publication. The Vilna Siddur has been reprinted by the Israeli Karaite community several times during the last decades 
compiled the first Karaite prayer book, Hebrew poems by Rabbanite authors were accepted as part of the Karaite tradition. ${ }^{9}$ As the Byzantine and Ottoman Karaite prayer books were intended for the benefit of both Turkish and East European Karaite communities, ${ }^{10}$ the Polish-Lithuanian Karaim tradition also contains many non-Karaite Hebrew poems. ${ }^{11}$

The vernacular of the early modern Karaim poets was Karaim, a Turkic (Kipchak) language. In the field of Karaim literature, nevertheless, the status of leshon ha-qodesh (Hebrew, the holy tongue) went uncontested. The Ten Principles of Karaite faith require that the believer know Hebrew; the principles were enumerated for the first time in the mediaeval Byzantine Empire and formed a sort of Karaite credo. ${ }^{12}$ Quite logically, therefore, the vernacular appears as the language of religious poetry somewhat later and with less prestige than Hebrew. ${ }^{13}$ In Karaim manuscripts, the Hebrew poems by Karaite (and occasionally by Rabbanite Jewish) authors are followed by Karaim translations (Heb. peshat ), ${ }^{14}$ which exhibit linguistic indebtedness to the Hebrew language and style. ${ }^{15}$ The purpose of the translations was to make the poems accessible also to Karaims with inadequate Hebrew skills, especially women (Kowalski 1929, p. xiii).

(e.g., in Ramle 1961). Earlier East European prayer books were published in Chufut-Kale in 1736/1737 and 1804, and in Gozlow in 1836. Besides prayer books, a few collections containing original Hebrew poetry by individual Karaim authors were printed later; Tehillot yisra'el edited by Y. Bizikovich and Y. B. Firkovich (1909), Iggeret niddehe shemu'el by S. S. Figit (1894), and Semah david by D. Kukizow (1897).

${ }_{9}^{9}$ By contrast, Karaite (and Karaim) poems were rarely, if ever, included to Rabbanite collections (Weinberger 1991, pp. 15-16). Obviously, the sheer volume of rabbinic Hebrew poetry is overwhelming when compared to the poetry written by the Karaite Jewish minority.

${ }^{10}$ The Chufut-Kale Siddur (1736/7), for example, is titled: Seder hat-tefillot le-minhag qehillot haq-qara'im asher bi-glilot qirim ve-qustandina va-haq-qehillot asher bi-mdinat polin "The prayer book in the custom of the Karaite congregations in the regions of the Crimea and Constantinople, and the congregations which are (located) in the country of Poland").

${ }^{11}$ For a concise list of the two-hundred and thirty paraliturgical poems published in the Vilna Siddur, including many rabbinic poems, see Tuori (2013, pp. 393-404).

${ }^{12}$ See, e.g., the principles in Adderet eliyahu (1532, pp. 55a-60a) by the Byzantine Karaite Eliya Bashyachi (circa 1420-1490). Polish-Lithuanian Karaims studied this legal codex regularly, as revealed by the 17th-century Lithuanian Karaim Shelomo ben Aharon in his Appiryon (Neubauer 1866, pp. 79-80).

${ }^{13}$ The earliest identified Karaims writing poetry in the vernacular or translating Hebrew poems into Karaim include, among others, the 16th-century Yiṣhaq ben Abraham of Troki (see, e.g., Kizilov 2009, p. 161).

${ }^{14}$ The rabbinic poem for weddings Le-felah ha-rimmon (Davidson 1970, Vol. II, p. 487), for example, merited several Karaim-language translations (Tuori 2013, p. 125, note 38).

${ }^{15}$ See, e.g., Nosonovsky (2011, pp. 25-26) who discusses the Hebrew influences in a peshat by the Volhynian Karaim Yosef ben Yeshu'a (mid-17th century). For an analysis of poetic prayers in Karaim, see, e.g., Olach (2014). For two modern collections of liturgical poetry in Karaim, see Ronne pallet (published in an appendix to the Volume III of the Vilna Siddur, 1890), and Saqun lahash (Dubinsky 1895). 


\section{Karaim Hebrew Poetry in Its Time: the Historical Context in Poland-Lithuania}

As a welcome trend in recent studies of Hebrew literature, poetry is no longer isolated "from its broader literary, social and historical setting" (Tanenbaum 2002, p. 4). Although religious Hebrew poetry leaves little room for personal views, poetry may supply (more or less) reliable historical information. ${ }^{16}$ Karaim Hebrew poems contain acrostics revealing the name of the author or his relatives or friends; poems for weddings, for example, often contain the names of the bride and bridegroom (Mann 1931, p. 555, note 7). ${ }^{17}$ Manuscripts supply the poems with introductory headings adding more details, including dates, locations, and honorifics.

The harsh economic conditions prevailing in Poland-Lithuania dictated the choice of occupation: Karaim poets could rarely work as full-time scholars but supported their families as merchants, leaseholders, or farmers. Headings for poems - both in manuscripts and in printed works - describe the Karaim poets as hakhamim (wise scholars), hazzanim (ritual experts), or morim (teachers). Such titles inform that the poets held central and respected positions in their communities. ${ }^{18}$ Many of the active poets of the period are also known not only as scholars but as characters in later Karaim folklore (see, e.g., Kizilov 2003): the talented but intellectually isolated Zerah ben Natan (d. 1657/1658, Troki), the miracle-working physicians Abraham ben Yoshiyahu (d. 1687, Troki) and Ezra ben Nisan (d. 1666, Troki), and scholars Mordokay ben Nisan (d. circa 1709, Kukizów) and Shelomo ben Aharon (d. 1745, Troki). ${ }^{19}$ All mastered Hebrew well enough to write original poetry, a talent which held prestige in all pre-modern Karaite and Rabbanite Jewish communities.

There are several examples of Karaim Hebrew poems discussing historical events. For example, the Troki-based Karaim scholar Shelomo ben Aharon wrote a qina (lamentation, "I shall awaken my heart to mourn") on the effects of the devastating plague, which took the lives of his wife and two sons in $1710 .^{20}$ The poet Yosef ben Yeshu'a (d. 1678, Derażne/Troki) mourns in biblical tones the horrors of the 1648 Chmielnicki massacres, which destroyed the Karaim community in Derażne, Volhynia: $^{21}$

\footnotetext{
${ }^{16}$ For one recent work discussing historical events and Hebrew poetry (the effects of the Crusades on mediaeval Ashkenazi Jews), see Einbinder (2002).

${ }^{17}$ One of the most prolific poets of the time, Shelomo ben Aharon (Troki, d. 1745), wrote poems especially for weddings embedding plenty of details about the event (Mann 1931, p. 740, note 187).

${ }^{18}$ On administrative positions in Karaim society in general, see Mann (1931, pp. 620-622).

${ }^{19}$ For concise biographies of the major poets of the period, see Tuori (2013, pp. 60-86).

${ }^{20}$ The Vilna Siddur, Vol. IV, pp. 260-261; for a Karaim version of the lamentation and its English translation, see Kizilov (2011).

${ }^{21}$ The Vilna Siddur, Vol. IV, pp. 110-111. The father of Yosef ben Yeshu'a was murdered in the attacks. For an analysis of his another poem on the massacres (Sahali ve-ronni) with a more detailed account of the events surrounding Chmielnicki and his Karaim victims, see von Rohden (2004), and Nosonovsky (2011).
} 
The remnant of the escaped people (Hab. 2:8) is silent (Hab. 2:19) and mute. $^{22}$

Poetry may also function as a tool for social supervision, enforcing desired behaviour. In his poem for the Feast of Tabernacles (Sukkot) (Vilna Siddur, Vol. IV, pp. 124-125), the poet Yosef ben Yișhaq (17th century, Troki) instructs his congregation to spend seven days in the tabernacles (Leviticus 23) and recounts the reasons for the celebrations of the Feast. In a hymn for the Sabbath of circumcision, the same poet expresses his expectations for the future of his infant son (Vilna Siddur, Vol. IV, pp. 115-116):

May he thrive in the good things of life, may he reach a suitable position, a good name in the fear of God, his splendour, and his majesty.

Poems subtly supply information about the values of the poet's surroundings, and the meaning of status on the rungs of Karaim society.

Finally, one peculiar intersection between poetry and contemporary history merits a reference, namely, different versions of Karaim Hebrew poems extant in manuscripts and in printed works. Variants arise from later editing process and, as such, are quite typical in the transmission of pre-modern Hebrew poetry. Differences are mostly minor and linguistic: editors of printed collections corrected grammatical errors or polished the Hebrew style to conform both the demands of the poetic metre and linguistic purity. ${ }^{23}$

Some of the differences between the versions are, however, more noteworthy from a historical and sociological point of view. For example, a few hand-written poems contain vehement accounts against the ruling (Christian) government. ${ }^{24}$ In one manuscript, ${ }^{25}$ the poet Yosef ben Shemu'el (probably of Halicz, d. circa 1700) writes the following line:

The holy of the nation, cover [it] in majesty, thresh the wrath of the Gentiles (Hab. 3:12)! Curse our haters and destroy their cities, and redeem the House of Jacob in the lands of the dispersed!

${ }^{22}$ The English translations of the poems are mine.

${ }^{23}$ See, e.g., the preface of Tehillot yisra'el (1909) by Bizikovich and Firkovich, where they explain the delicate balance between the realisation of the poetic metre and linguistic correctness. The problem was acute also in the case of Karaim-language poetry; see Simha Dubinsky's collection of Karaim liturgical poetry, Saqun lahash (Vilna 1895, p. III), where he harshly criticises the quality of earlier Karaim translations.

${ }^{24}$ Asking for divine intervention and revenge on the enemies (for example, Esau and his biblical epithets representing the enemy, e.g., Christians or Muslims depending on the context) is a recurring theme in Hebrew poetry, beginning already in the Book of Psalms. Later many controversial expressions in mediaeval Hebrew poetry were censored (van Bekkum 2007, p. 238).

${ }^{25}$ Ms. A065, fol. 187a (Zemirot le-shabbetot hash-shana ke-minhag qara'im, Institute of Oriental Studies of the Russian Academy in St. Petersburg, copied in 1861). 
In the Vilna Siddur (pp. 206-207), edited by Felix Malecki in 1890-1892, the reading is significantly milder, the biblical reference to Gentiles is cut in half, and cities are no longer threatened with destruction:

The holy of the nation, cover [it] in majesty, thresh the wrath (Hab. 3:12) of the rebellious ones. This nation that you formed (Ex. 15:16, Is. 43:21) shall sing songs to you, and all that you have created shall praise you, the pure ones!

For reasons of heightened political awareness and fear of anti-Karaim stance, potentially precarious phrases were censored in 18th- and 19th-century printed editions. Variants are relevant for the study of modern Karaim history and their delicate relations with the Polish and, later, Russian government. ${ }^{26}$

\section{The Andalusian Tradition of Hebrew Poetics and the Karaims}

The standard of quantitative metrics, based on a regular alteration between long and short syllables, was originally adapted into Hebrew from Arabic by Sephardic Jewish poets in the 10th-century Andalusia. ${ }^{27}$ Recently Yeshaya $(2011,2014)$ published two critical editions of hundreds of poems by the 12th-century Egyptian Karaite Moshe Dar ' 1 ; most of the secular poems by this mediaeval poet employ the quantitative metre. According to Weinberger (1998, pp. 412-413), mediaeval Byzantine Karaite Hebrew poetry also follows the quantitative metric system. ${ }^{28}$

A mere glance at the arrangement of the lines in Karaim Hebrew (especially paraliturgical) poetry confirms that Karaims also prefer to write quantitative poetry. It is highly likely that the Karaims became acquainted with this standard of mediaeval Hebrew poetics via the shared literary heritage (letters, theological works, and collections of religious poems) of East European and Byzantine-Ottoman communities. ${ }^{29}$

As Karaim Hebrew poetry represents an uninterrupted continuation of an established Karaite literary culture, the Karaims were turning towards literary sources produced outside Eastern Europe. Thus, Karaim Hebrew poetry represents a unique corpus in its European context: although connected by their mutual literary language (Hebrew) and geographic proximity, the Karaims did not share the same cultural interests with the Ashkenazi Jews, at least in the field of poetics. Ashkenazi Jews, although

${ }^{26}$ Ideological, religious, and political motivations behind censorship have been discussed by Poznański (1918a, 1918b), Goldberg (1957, p. 108), and Miller (1993, p. 17). Observations and translations of variants between manuscripts and paraliturgical poems (zemirot) in the Vilna Siddur, see Tuori (2013, pp. 241-243).

${ }^{27}$ For a detailed discussion on the history and form of mediaeval Andalusian (Hispano-Hebrew) poetry, see Fleischer (1975) and Pagis (1976).

${ }^{28}$ The first Byzantine Karaite poet to use Andalusian metrics is the 11th-century Tobiyya ben Moshe (Weinberger 1998, p. 412). pp. 698 ff.).

${ }^{29}$ On the close connections and correspondence between the communities, see Mann (1931, 
occasionally imitating the Andalusian poets, preferred the Palestinian tradition of writing poetry (piyyutim) following different prosodic standards (Harshav 2007, p. 597). ${ }^{30}$ Linguistics also played a role in the choice of poetics: the Ashkenazi pronunciation of Hebrew differs crucially from the Sephardic pronunciation; by contrast, East European Karaim pronunciation suits exceptionally well with the Andalusian (Sephardic) prosody. ${ }^{31}$

The form, metre, rhyme, as well as themes and topics of religious Hebrew poetry are highly formalistic. Bound by tradition, Karaim poets rarely break conventions or invent new poetic forms. The writing of Hebrew poetry in the quantitative metre is a type of artisanship requiring years of education. To this end, Karaim poets - like most pre-modern Hebrew poets - studied grammar, poetic guidebooks, and alphabetic lists of rhyme endings, which aided the aspiring poet in finding proper rhymes for their verse (Tobi 1986, p. 39). ${ }^{32}$ The Andalusian tradition was also essential for the formal models of Karaim Hebrew poetry: Karaims culled model poems from the Sephardic rabbinic repertoire, and poems by later (Byzantine or Ottoman) Karaite and Rabbanite poets were imitated. Imitation was very common during the mediaeval period and was conducted both by Arabic and Hebrew poets. ${ }^{33}$ The practice should not be understood as plagiarism but, rather, as a sign of esteem and popularity of the original literary work. There was no need to hide the source of inspiration, and Karaim manuscripts customarily supply the name of the original poem in the heading preceding the new product. Knowing the original rendered the new poem (and its melody) instantly familiar to reciters and thus facilitated the memorisation of the novel lyrics. $^{34}$

${ }^{30}$ The closeness of Karaim and Sephardic poetic traditions, as opposed to the tradition of the local Ashkenazi Jews, has also been noticed by Kashani (1978, p. 64) and Idelsohn (1932, p. 154). Furthermore, Sephardic paraliturgical collections contain many hymns by the Andalusian and Ottoman poets, which were never adapted into Ashkenazi repertoires but are found in East European Karaim collections (Idelsohn 1932, p. 154). About the occasionally strained relations between the Ashkenazim and Karaims in early modern Europe, see, e.g., Schreiner (1999).

${ }^{31}$ On Karaim pronunciation of Hebrew and its closeness to Sephardic traditions of Hebrew, see Harviainen (1992).

${ }^{32}$ Evidence on poetic guides in Karaim hands exists: the Rabbanite scholar Yosef Shelomo Delmedigo recommends an alphabetic guide of Hebrew rhymes to his Karaim correspondent Zerah ben Natan (Geiger 1840, pp. 14-16). On the 17th-century Rabbanite scholar Delmedigo and his relationship with the Karaims, see Schreiner (1999).

${ }^{33}$ More on the formal aspects and imitation as a fertile technique in paraliturgical Karaite Hebrew poetry, see Tuori (2013, pp. 115 ff.); on imitation in mediaeval Andalusian poetry in Hebrew, see Stern (1974, pp. 45-49).

${ }^{34}$ For example, the poem Eqra be-shevah by the Karaim physician Ezra ben Nisan (d. 1666, Troki) is sung in the melody of Ki eshmera, a mediaeval poem for the Sabbath, often ascribed to the Spanish Rabbanite poet Abraham ibn Ezra; see Ms. A065, fol. 155a (Zemirot leshabbetot hash-shana ke-minhag qara'im, Institute of Oriental Studies of the Russian Academy in St. Petersburg, copied in 1861). Unfortunately, the melodies of Karaim poems in Hebrew are no longer extant; on Lithuanian Karaim music, see Firkavičiūtė (2003). 


\section{Karaim Poets as Theologians and Philosophers?}

If a Karaim scholar wants to cover a certain theological or philosophical topic comprehensively, he will certainly choose prose - instead of poetry - as his main medium. May Hebrew poetry, then, be used in tracing the prevailing intellectual trends of Polish-Lithuanian Karaims? Despite the challenges posed by the recondite language of poetry, scholars have lately become more open to such possibilities: according to Tanenbaum $(2002$, p. 6 ), for example, poetry may function as "a serious source for intellectual history".

The scrutiny may begin from the Karaim stance to the biblical corpus. The phraseology of their religious Hebrew poems bears a strong resemblance to the imagery employed in the Hebrew Bible: the poets anticipate redemption and messianic salvation, and the rebuilding of the Temple - all biblical themes with a strong presence in Karaite liturgy. ${ }^{35}$ Moreover, the poems contain references to mediaeval Karaite and rabbinic biblical exegesis. A meticulous analysis of Karaim poetry and its relationship to mediaeval Karaite commentaries is likely to reveal independent and uninterrupted Karaite tradition preserved in early modern Eastern Europe. ${ }^{36}$

Besides biblical quotations, Karaim Hebrew poems are bursting with philosophical and mystical allusions. These intertextual puns are useful indicators of PolishLithuanian Karaim scholarly activities. The most dominant philosophical tradition is mediaeval Jewish Neo-Platonism: the poets play with the images of the soul, intellect, emanation, and divine light. Similar themes are present in the foremost model of Karaim Hebrew poets, the Byzantine Karaite poetry. ${ }^{37}$

Although formally dependent on Sephardic Jewish models, Karaim Hebrew poets write Karaite poetry, which, as well, bonds them with their Byzantine co-religionists. Karaite ideology surfaces expressly in the poems dedicated to the celebration of festivals, which traditionally differ from the rabbinic practice, for example, in the fixing of the correct date for the Feast of the Weeks (Shavu'ot), ${ }^{38}$ and in the orthodox

\footnotetext{
${ }^{35}$ In contrast to rabbinic liturgy with a substantial amount of post-biblical material, Karaite liturgy is based on biblical florilegia and quotations (Frank 2003, pp. 561-563).

${ }^{36}$ For quotations from mediaeval exegetical literature (including the Rabbanites Abraham ibn Ezra and Nahmanides, etc.) in Karaim zemirot, see Tuori (2013, pp. 234-235). The most likely source for Karaite exegetical quotations is the Byzantine Aharon ben Yosef (d. 1240), the author of the major commentary on the Torah, Sefer ha-mivhar. This commentary was studied by the Karaims on a weekly basis, as revealed by the 17th-century Lithuanian Karaim Shelomo ben Aharon in his Appiryon (Neubauer 1866, pp. 79-80).

${ }^{37}$ For the appearance of philosophical, scientific, and mystical allusions in Karaim paraliturgical poetry, see Tuori (2013, pp. 228-239); in Byzantine Karaite poetry, see Weinberger (1991, pp. 39-44). On the influence of Kabbalah (Jewish esoteric traditions) in Karaim thought, see Lasker (2004), and Tuori (2014).

${ }^{38}$ In contrast to Rabbanites, Karaites begin the counting of the grain offering ('omer) on the day following Saturday ('morrow after Sabbath', from Lev. 23:15), that is, on the following Sunday after the first day of Pesah. Therefore Shavu ot always falls on a Sunday. According to rabbinic interpretation, the 'morrow after Sabbath' is any day after the first day of Pesah. The Karaite calculation is emphasised in Karaim zemirot for Shavu ot as the correct interpretation (Tuori 2013, p. 226).
} 
Karaite observance of the Sabbath. ${ }^{39}$ Furthermore, adjectives used to describe the Karaims underscore their intellectual superiority; ${ }^{40}$ the identity of the Karaims as independent Hebrew poets is never in doubt.

\section{Final Remarks}

This paper has aimed to clarify how Hebrew poetry was an integral part of early modern Karaim culture and religious life. Prayer books and collections with dozens of local poems are convincing pieces of evidence that Hebrew poetry was a popular and entertaining activity among Karaim scholars. Religious poems typically had a didactic purpose, namely, to teach the younger members of the congregation about the basics of Karaite faith, but contemporary topics were not avoided either: hymns were written to celebrate the newlyweds, and lamentations to mourn the deceased. In terms of form and content, Karaim Hebrew poetry is indebted to the examples provided by the Byzantine Karaite poets. Moreover, while following the footsteps of these poetic predecessors, Karaim Hebrew poetry grants a unique glimpse of the intellectual trends present in Karaim theology and philosophy in early modern Europe.

\section{References}

Akhiezer, G. - Shapira, D. (2001): Qara'im be-lița u-be-vohlin-galișya 'ad ham-me'a hay-yod-ḥet [Karaites in Lithuania and in Volhynia-Galicia until the 18th century]. Pe 'amim 89, pp. $19-60$.

Bashyachi, E. (1532): Adderet eliyahu [The mantle of Eliyyahu]. Constantinople.

van Bekkum, W. (2007): Some Thoughts on the 'Secularization' of Hebrew Liturgical Poetry in Pre-Modern and Modern Times. In: Fontaine, R. - Schatz, A. - Zwiep, I. (eds): Sepharad in Ashkenaz: Medieval Knowledge and Eighteenth-Century Enlightened Jewish Discourse. Amsterdam, pp. 235-247.

Bizikovich Y. - Firkovich Y. B. (1909): Tehillot yisra' el [The praises of Israel]. Berditshev.

Davidson, I. (1970): Thesaurus of Mediaeval Hebrew Poetry. Volumes I-IV. New York.

Dubinsky, S. (1895): Șaqun lahash [Silent prayer]. Vilna.

Einbinder, S. L. (2002): Beautiful Death: Jewish Poetry and Martyrdom in Medieval France. Princeton.

Figit, S. S. (1894): Iggeret niddehe shemu'el [The letter of the dispersed of Samuel]. St. Petersburg.

Firkavičiūtè, K. (2003): The Musical Heritage of Lithuania's Karaims. In: Polliack, M. (ed.): Karaite Judaism: A Guide to its History and Literary Studies. Leiden, pp. 855-871.

Fleischer, E. (1975): Shirat haq-qodesh ha- ivrit bime hab-benayim [Sacred Hebrew poetry in the Middle Ages]. Jerusalem.

${ }^{39}$ The concept of the Sabbath delight ('oneg shabbat) is most enlightening: Karaism forbids sex on the Sabbath, while rabbinic Judaism considers marital relations part of the Sabbath delights. In Karaim zemirot for Sabbath, the issue is dealt with polemically (Tuori 2013, pp. 222-223).

${ }^{40}$ In Karaim paraliturgical poetry, self-appellations include 'wise men', 'the ones who know the foundations of the Scripture', and 'the sages' (Tuori 2013, p. 240, pp. 412-414). 
Frank, D. (2003): Karaite Prayer and Liturgy. In: Karaite Judaism: A Guide to its History and Literary Studies. Leiden, pp. 559-589.

Geiger, A. (1840): Melo' hofnayim [A full handful]. Berlin.

Gierowski, J. A. (1996): The Polish-Lithuanian Commonwealth in the XVIIIth Century. Kraków.

Goldberg, P. S. (1957): Karaite Liturgy and its Relation to Synagogue Worship. Manchester.

Harshav, B. (2007): Prosody, Hebrew. In: Berenbaum, M.-Skolnik, F. (eds): Encyclopedia Judaica. Detroit, Vol. 16, pp. 595-623.

Harviainen, T. (1992): The Karaites of Lithuania at the Present Time and the Pronunciation Tradition of Hebrew among Them: A Preliminary Survey. In: Dotan, A. (ed.): Proceedings of the Ninth Congress of the International Organization for Masoretic Studies 1989. Atlanta, pp. $53-69$.

Harviainen, T. (2003): The Karaites in Eastern Europe and the Crimea: An Overview. In: Polliack, M. (ed.): Karaite Judaism: A Guide to Its History and Literary Studies. Leiden, pp. $633-655$.

Hundert, G. (2004): Jews in Poland-Lithuania in the Eighteenth Century. A Genealogy of Modernity. Berkeley, Los Angeles.

Idelsohn, A.Z. (1932): Jewish Liturgy and its Development. New York.

Kashani, R. (1978): Haq-qara 'im. Qorot, masorot u-minhagim [The Karaites: history, traditions and customs]. Jerusalem.

Kizilov, M. (2003): Ezra ben Nisan ha-Rofe of Troki (1595-1666) - A Karaite Physician in Legend and History. Leipziger Beiträge zur jüdischen Geschichte und Kultur, pp. 83-103.

Kizilov, M. (2009): The Karaites of Galicia: an Ethnoreligious Minority among the Ashkenazim, the Turks, and the Slavs, 1772-1945. Leiden.

Kizilov, M. (2011): The Lithuanian Plague of 1710 and the Karaites. A Poem of Lament in the Karaim Language from Tadeusz Kowalski's Archival Collection. Lituanus 57/2. Accessed online (30.10.2014): http://www.lituanus.org/2011/11 2 03Kizilov.html.

Kollender, R. (2003): Melodic Patterns in Karaite Music: Past and Present. In: Polliack, M. (ed.): Karaite Judaism: A Guide to its History and Literary Studies. Leiden, pp. 471-481.

Kukizow, D. (1897): Semah david [The plant of David]. St. Petersburg.

Kowalski, T. (1929): Karaimische Texte im Dialekt von Troki. Kraków.

Lasker, D. (2004): Simḥa yiṣhaq luṣki: mequbbal qara'i ben ham-ma'a hay-yod-ḥet [Simha Isaac Lucki: The Karaite Kabbalist from the 18th century]. In: Gries, Z.-Huss, B. (eds): Shefa tal: 'iyyunim be-mahshevet yisra'el u-ve-tarbut yehudit (muggashim le-Bracha Zaq) [The abundance of dew: studies in the thought of Israel and Jewish culture (offered to Bracha Zaq)]. Beersheva, pp. 171-190.

Mann, J. (1931): Texts and Studies in Jewish History and Literature, Volume II. Cincinnati.

Miller, P. (1993): Prayer Book Politics: An Attempt to Print the Karaite Siddur in 1866 that was Canceled. Studies in Bibliography and Booklore 18, pp. 15-26.

Neubauer, A. (1866): Aus der Petersburger Bibliothek. Beiträge und Documente zur Geschichte des Karäerthums und der karäischen Literatur. Leipzig.

Nosonovsky, M. (2011): The Karaite Community in Deražne and its Leader Hazzān Joseph ben Yeshu'ah. In: Shapira, D. - Lasker, D. (eds): Eastern European Karaites in the Last Generations. Jerusalem, pp. 17-35.

Olach, Z. (2014): A Comparative Study of Two Evening Prayers Written in Karaim. In: Demir, N.Karakoç, B. - Menz, A. (eds): Turcology and Linguistics. Éva Ágnes Csató Festschrift. Ankara, pp. 313-326.

Pagis, D. (1976): Hiddush u-masoret be-shirat ha-hol ha- ivrit [Innovation and tradition in secular Hebrew poetry]. Jerusalem. 
Poznański, S. (1918a): Karäische Drucke und Druckereien. Zeitschrift für Hebräische Bibliographia Vol. 21, Nos 1-3, pp. 32-48.

Poznański, S. (1918b): Karäische Drucke und Druckereien. Zeitschrift für Hebräische Bibliographia Vol. 21, Nos 4-6, pp. 66-83.

von Rohden, F. (2004): Karäisches Gedenken der Khmelnytsky-Verfolgungen: ein Piyut von 1650. Judaica Vol. 60, No. 2, pp. 159-169.

Rosman, M. (1990): The Lords' Jews. Magnate-Jewish Relations in the Polish-Lithuanian Commonwealth during the Eighteenth Century. Cambridge, Massachusetts.

Schirmann, H. (1995): Toledot hash-shira ha- ivrit bi-sfarad ham-muslemi [The history of Hebrew poetry in Muslim Spain]. Jerusalem.

Schreiner, S. (1999): Delmedigos Bild der Polnisch-Litauischen Juden - Erfahrungen aus Fünf Jahren. Studia Judaica Vol. 2, No. 4, pp. 165-183.

Stern, S. M. (1974): Hispano-Arabic Strophic Poetry. Oxford.

Tanenbaum, A. (2002): The Contemplative Soul. Hebrew Poetry and Philosophical Theory in Medieval Spain. Leiden.

Tobi, Y. (1986): Hash-shira ha-'ivrit ba-arșot-ham-mizrạ le-ahar hag-gerush [Hebrew poetry in Oriental Lands after the Expulsion]. Pe 'amim 26, pp. 29-45.

Tuori, R. (2011): "More Didactic than Lyrical": Modern Views on Karaite Hebrew Poetry. SO Vol. 111 , pp. 371-392.

Tuori, R. (2013): Karaite Zemirot in Poland-Lithuania. A Study of Paraliturgical Poems from the Seventeenth and Eighteenth Centuries. Helsinki.

Tuori, R. (2014): Karaites and Kabbalah. Cooperation and Conflict in the Seventeenth-century Poland-Lithuania. In: Lindstedt, I. - Hämeen-Anttila, J. - Mattila, R. - Rollinger, R. (eds): Case Studies in Transmission. Münster, pp. 189-199.

Vilna Siddur (1890-1892): Siddur hat-tefillot ke-minhag haq-qara'im [The prayer book in the custom of the Karaites]. Vols I-IV. Vilna.

Walfish, B. - Kizilov M. (2011): Bibliographica Karaitica. An Annotated Bibliography of Karaites and Karaism. Leiden.

Weinberger, L. J. (1991): Rabbanite and Karaite Liturgical Poetry in South-Eastern Europe. Critical Edition with Introduction and Commentary by Leon J. Weinberger. Cincinnati.

Weinberger, L. J. (1998): Jewish Hymnography: A Literary History. London-Portland, Oregon.

Yeshaya, J. (2011): Medieval Hebrew Poetry in Muslim Egypt. Leiden.

Yeshaya, J. (2014): Poetry and Memory in Karaite Prayer. Leiden. 